\title{
REGIONALISING INTERNATIONAL REFUGEE LAW IN THE EUROPEAN UNION: DEMOCRATIC REVISION OR REVISIONIST DEMOCRACY?
}

\author{
Jane McAdam*
}

\begin{abstract}
This paper questions whether the process of harmonisation of the European Union's asylum laws has strengthened the region's commitment to international law and international standards, or has instead diluted them in order to accommodate regional (and domestic "democratic") concerns about forced migration. Harmonisation has taken place in a political environment that is suspicious of asylum seekers, that seeks restrictive entrance policies and that is wary of large numbers of refugees. This paper argues that such factors have heavily influenced the scope of the common asylum laws - who is eligible for protection - and the rights to which beneficiaries are entitled what that protection actually is. It looks in particular at the confinement of protection to "third country nationals", a restriction which contravenes the 1951 Refugee Convention and denies international protection to groups within the EU such as the Roma, whose discrimination is welldocumented and has historically led to many being recognised as refugees. Furthermore, the paper considers that the EU citizen's right to free movement is not synonymous with a right to residence, and is especially complicated for nationals of the 12 new accession States. It argues that harmonisation has occurred at the expense of a comprehensive and systematic analysis of international law, responding instead to "democratic" political compromise and pragmatism.
\end{abstract}

\section{INTRODUCTION}

At the start of the $20^{\text {th }}$ century, European nations stood at the forefront of initiatives to create a body of international refugee law. The result was a number of international arrangements and agreements about refugees, culminating in the 1951 Convention relating to the Status of Refugees and its 1967 Protocol. ${ }^{1}$ Yet, at the beginning of the $21^{\text {st }}$ century, the European Union (EU) turned

BA(Hons) LLB(Hons) (Syd) DPhil (Oxon); Senior Lecturer and Director of International Law Programmes, Faculty of Law, University of New South Wales. Thank you very much to Dr María-Teresa Gil-Bazo of the University of Newcastle (UK) and Dr Katja Ziegler of the University of Oxford for their helpful comments on an earlier draft of this paper. Any errors remain, of course, my own. This article refers primarily to the 
its attention to the creation of a "Common European Asylum System", seeking to harmonise State practice across the EU by establishing minimum standards for receiving and hosting refugees and asylum seekers. Its first phase was completed at the end of April 2004, with the adoption of three binding Directives on temporary protection, reception conditions, and qualification for international protection, ${ }^{2}$ and political agreement (subsequently formalised in law) was reached on a Directive about asylum procedures. ${ }^{3}$

Harmonisation is intended to create a consistent minimum level of protection throughout the EU by reducing disparities between national legislation and practice, and thereby avoiding refugee flows between EU Member States based solely on differing levels of protection. However, in the process of formulating a regional approach to asylum issues, there has been a considerable narrowing of Member State "best practice", both in terms of who is eligible for protection and their resultant legal status. The instruction in the Treaty establishing the European Community (TEC) $)^{4}$ to adopt "minimum standards" on asylum has been taken very literally, with the asylum Directives frequently adopting lowest common denominator standards instead of aiming for the higher standards afforded by some Member States. ${ }^{5}$ Harmonisation has occurred at the expense of a comprehensive and systematic analysis of international law, responding instead to "democratic" political compromise and pragmatism.

situation following the accession of 10 new Member States to the EU on 1 May 2004, but is also applicable to the accession on 1 January 2007 of two new Member States (Bulgaria and Romania).

1 Convention relating to the Status of Refugees (28 July 1951) 189 UNTS 137 [Refugee Convention]; Protocol relating to the Status of Refugees (31 January 1967) 606 UNTS 267.

2 Council Directive 2001/55/EC on Minimum Standards for Giving Temporary Protection in the Event of a Mass Influx of Displaced Persons and on Measures Promoting a Balance of Efforts between Member States in Receiving Such Persons and Bearing the Consequences thereof [2001] OJ L212/12; Council Directive 2003/9/EC Laying Down Minimum Standards for the Reception of Asylum Seekers [2003] OJ L31/18; Council Directive 2004/83/EC on Minimum Standards for the Qualification and Status of Third Country Nationals or Stateless Persons as Refugees or as Persons Who Otherwise Need International Protection and the Content of the Protection Granted [2004] OJ L304/12 [Qualification Directive]. The Dublin Regulation was also concluded: Council Regulation (EC) No 343/2003 of 18 February 2003 establishing the Criteria and Mechanisms for Determining the Member State Responsible for Examining an Asylum Application Lodged in One of the Member States by a Third-Country National [2003] OJ L50/1.

3 Council Directive 2005/85/EC on Minimum Standards on Procedures in Member States for Granting and Withdrawing Refugee Status [2005] OJ L326/13 [Procedures Directive].

4 Treaty establishing the European Community (consolidated text) [2002] OJ C 325/33 [TEC], art 63.

5 This means that Member States which followed higher standards may reduce them as part of harmonisation, or may choose to maintain them: Qualification Directive, above n 2, art 3, recital 8. This calls into question how effective "harmonisation" will actually be: see for example H Storey and others "Complementary Protection: Should There Be a Common Approach to Providing Protection to Persons Who Are Not Covered by the 1951 Geneva Convention?" (Joint Immigration Law Practitioners' Association/International Association of Refugee Law Judges Symposium, London, 6 December 1999) (copy with author). 
Although harmonisation was supposed to take place "in accordance with the Geneva Convention of 28 July 1951 and the Protocol of 31 January 1967 relating to the status of refugees and other relevant treaties", 6 there are a number of areas where international law has been undermined by regional interpretations. One of these, which is central to the very concept of international protection, is the definition of a "refugee".

The 1951 Refugee Convention defines a "refugee" as someone who

owing to well-founded fear of being persecuted for reasons of race, religion, nationality, membership of

a particular social group or political opinion, is outside the country of his nationality and is unable, or

owing to such fear, is unwilling to avail himself of the protection of that country; or who, not having a

nationality and being outside the country of his former habitual residence as a result of such events, is

unable or, owing to such fear, is unwilling to return to it. ${ }^{7}$

Until 1967, Contracting States could make a declaration on ratification restricting refugee status to persons who had fled persecution as a result of "events occurring in Europe before 1 January 1951". ${ }^{8}$ However, the Protocol to the Convention (which entered into force on 4 October 1967) removed this geographical and temporal restriction so that the refugee definition became truly universal. States which had imposed declarations were encouraged to lift them, and the five (now) EU Member States with declarations did so. ${ }^{9}$ Furthermore, article 42 of the Refugee Convention prohibits Contracting States from amending the refugee definition in any manner.

However, the definition of a "refugee" in the EU is confined to "third country nationals"—-that is, nationals of countries which are not part of the EU. ${ }^{10}$ From a political perspective, one might appreciate why this is so. First, some would question whether individuals can be subject to persecution (or other forms of serious harm ${ }^{11}$ ) in a region in which all Member States have, as a condition of membership, accepted various human rights treaties as a matter of both law and

6 TEC, above $\mathrm{n} 4$, art 63(1).

7 Additionally, human rights instruments, such as the Convention against Torture and Other Cruel, Inhuman or Degrading Treatment or Punishment and the International Covenant on Civil and Political Rights, have expanded the categories of people whom States cannot remove by prohibiting States from removing people to torture or cruel, inhuman or degrading treatment or punishment. Such "complementary protection" is strengthened in Europe by article 3 of the European Convention on Human Rights (4 November 1950) 213 UNTS 221, ETS No 5 [ECHR], which binds all of the EU Member States as well as other members of the Council of Europe.

8 Refugee Convention, above n 1, art 1B.

9 France (1971), Luxembourg (1971), Portugal (1976), Italy (1990), Hungary (1998).

10 Qualification Directive, above n 2, art 2(c). This builds on the earlier 1997 Protocol on Asylum for Nationals of Member States of the European Union, discussed below.

11 Subsidiary protection, based on human rights abuses, is also restricted to third country nationals. 
practice. Secondly, even if it were possible for an EU national to be persecuted in his or her country of origin, by virtue of that regional "citizenship", he or she has a right to freedom of movement and can therefore escape persecution by relocating to another Member State. Accordingly, the argument goes, such a person is not a refugee and there is no need for asylum to be granted. Both these arguments are flawed, however, not least because there is evidence of groups severely discriminated against in certain parts of Europe (such as the Roma), and the right to residence in other EU countries is not as simple as having a right to free movement. The latter is compounded for those most likely to need international protection, given the restrictions on free movement which the existing 15 Member States imposed on the 10 new Member States at the time of their accession on 1 May 2004. ${ }^{12}$

It is here that the conflict between the nation-state and the regional EU is perhaps most awkward. This, in turn, highlights discrepancies between States' obligations under regional legislation and international law. Member States cannot simply abrogate their responsibilities under international treaties by entering into regional agreements. ${ }^{13}$ Accordingly, even though EC law ${ }^{14}$ now contains a harmonised approach to determination of refugee status for non-EU nationals, EU citizens who are refugees must still be able to have their claims assessed on the basis of international law. How this will operate, and whether it will in substance differ from the EC law approach, remains to be seen. The defining-out of such persons from the EC Qualification Directive makes a political statement, but one which cannot operate as a matter of international law. Yet, as Costello notes: 15

this argument, although legally correct, cannot quell unease at the Member State governments' legislative practices in the Council. In several fundamental rights-sensitive areas, governments are legislating in a manner that apparently affords themselves the power to violate fundamental rights. When complaints are raised, they revert to the mode of State as the bearer of international legal obligation (rather than the government as part of an EU horse-trading legislative body) and assert that all's well for fundamental rights, as these self-same governments can be trusted to adhere to the standards they so patently attempt to undermine in rewriting fundamental rights in EC legislation.

12 Note that two more States joined the EU on 1 January 2007: Bulgaria and Romania.

13 Matthews $v$ United Kingdom (1999) 28 EHRR 361; TI v United Kingdom [2000] INLR 211. See below for the circumstances in which this may be possible.

14 "EC law" denotes law adopted as an instrument of the European Community, as opposed to transgovernmental agreements between Member States.

15 Cathryn Costello "The Bosphorus Ruling of the European Court of Human Rights: Fundamental Rights and Blurred Boundaries in Europe" (2006) 6 Human Rights Law Review 87; Elspeth Guild "Seeking Asylum: Storm Clouds between International Commitments and EU Legislative Measures" (2004) 29 European Law Review 198, 122-23. 
This paper questions whether the process of harmonisation has strengthened the region's commitment to international law and international standards, or has instead diluted it in order to accommodate regional (and domestic "democratic") concerns about forced migration. Harmonisation has taken place in a political environment that is suspicious of asylum seekers, that seeks restrictive entrance policies and that is wary of large numbers of refugees. These concerns have been central to national elections over the past decade, and have encouraged the "Fortress Europe" mentality. Yet, they have also fed into ideas about EU enlargement and how the existing Member States should accommodate the new "EU citizen" status of nationals of the eight former eastern bloc countries which joined the EU (along with Malta and Cyprus) in May 2004. The conceptual blurring between "asylum" and "economic migration", a hallmark of the EU approach to protection, infiltrated concerns about enlargement as well: on the one hand, fear of floods of migrants from the new EU Member States coming to take westerners' jobs; and on the other, a fear that the new external borders of the EU might not be sufficiently strong to prevent influxes of asylum seekers from their edges.

In doing so, this paper does not necessarily presuppose that international law is more "democratic" than EC law, although it does maintain that obligations assumed under international human rights and refugee law must not be abrogated for "regional interest" reasons, just as they must not bend to national imperatives. This is even more complex in the EU structure, where the domestic political concerns of Member States may inform regional law, but be rendered invisible by EC law's supranational (and, in theory, horizontal) status. Article 6 of the Treaty on European Union (TEU) requires the EU to respect fundamental rights as general principles of EC law, and accordingly the EU's objectives under article 2 are subordinate to this overarching requirement. For this reason, human rights law must guide asylum law, which means "nothing less than a reintroduction of the universalist perspective". ${ }^{16}$ This paper therefore suggests that EC law must not be viewed as a self-legitimising regime on the basis of (lowest common denominator) agreements between Member States, even if those agreements are responsive to (but perhaps also constitutive of) the security-based immigration concerns of national constituencies. Instead, it must be held accountable to the international obligations which Member States have undertaken. ${ }^{17}$ Since the EU itself cannot presently accede to international human rights treaties, the EC-international law interface exposes one of the main paradoxes of Europeanisation: the coveted single "European" actor's lack of formal international legal personality necessitates the preservation of the traditional nation State. The goal of a univocal Union is thus subverted by the Westphalian system of States.

16 Gregor Noll and Jens Vedsted-Hansen "Non-Communitarians: Refugee and Asylum Policies" in Phillip Alston (ed) The EU and Human Rights (Oxford University Press, Oxford, 1999) 364.

17 See below for discussion of the circumstances in which international obligations may be denounced. 


\section{THE DOMESTIC POLITICAL SITUATION}

The attitude of western States towards asylum can be described as "organised hypocrisy": 18 States affirm the principle of asylum (for "genuine" refugees) while devising every conceivable mechanism to prevent asylum seekers from entering their territories. There is a perception, perpetuated by certain sectors of the media, that Europe is facing a refugee crisis. ${ }^{19}$ In 2003, the United Kingdom tabloid the Daily Mail reported that $82 \%$ of those interviewed believed that the UK's immigration policies were "not tough enough", and $80 \%$ agreed that "the problem of asylum seekers is out of control". ${ }^{20}$ Perhaps this was not surprising, given that the top two "asylum" themes in the The Guardian, The Independent and the Daily Telegraph that year were (a) exclusion policies targeting "bogus" asylum seekers ${ }^{21}$ and (b) crime or terrorism perpetrated by asylum seekers. ${ }^{22}$ Some of the more emotive front page headlines of the Daily Express tabloid included "Bombers are All Spongeing Asylum Seekers", "Asylum Scandal of Baby Killer", "Asylum Seekers Cost Us £1Bn a Year", "Asylum Seeker's £6M Slave Trade in Britain", and "1 in 4 Terror Suspects are Asylum Seekers". 23

Yet, as Amnesty International has noted, the EU is "not going through an 'asylum crisis' but rather through a 'protection crisis'."24 Since 2001, the numbers of people claiming asylum have in fact decreased. In 2004, there were $20 \%$ fewer claims than in 2003 , which represented $36 \%$ fewer

18 Matthew J Gibney The Ethics and Politics of Asylum: Liberal Democracy and the Response to Refugees (Cambridge University Press, Cambridge, 2004) 229, adopting the terminology of Stephen Krasner Sovereignty: Organised Hypocrisy (Princeton University Press, Princeton, 1999).

19 This has been a recurring historical theme, however. See Lionel Morrison "Refugees Feature: Negative Media Coverage: The Same Old Story" http://news.amnesty.org (accessed 1 March 2007), detailing headlines from the $1930 \mathrm{~s}, 60 \mathrm{~s}$ and $70 \mathrm{~s}$.

20 "Asylum Problem 'Out of Control"' (18 August 2003) Daily Mail London. The phrasing of the question itself highlights the confused fusion of "immigration" and "refugee" law.

21 This was mentioned in $73 \%$ of The Guardian articles, $80 \%$ of The Independent and $73 \%$ of the Daily Telegraph. The study was based on website searches of each newspaper using the terms "asylum", "asylum seeker(s)", "immigration" and "refugee(s)". The top 30 articles displaying any of these keywords were used as a representative sample. See Matthew Randall "Asylum and Immigration: Comparing the Daily Telegraph, The Guardian and The Independent" (Media Lens Media Alert, 8 December 2003) www.medialens.org (accessed 30 May 2007).

$2256 \%$ The Guardian, 60\% The Independent, 66\% Daily Telegraph, as cited in ibid.

23 Cited in Rupert Colville "Words and Images" (2006) 142 Refugees 14, 16-17. The headlines appeared between 2001 and 2006. Colville notes that the Daily Express produced 22 anti-asylum front pages in one 31-day period.

24 Daphné Bouteillet-Paquet "EU Regional Protection Programs: Enhancing Protection in the Region or Barring Access to the EU Territory?" (Amnesty International EU Office, September 2005) Press Release (emphasis in original). 
claims than in $2001 .^{25}$ Nevertheless, Member States have increasingly devised interception and deflection strategies to prevent asylum seekers from ever reaching their territories, even though "the movement of asylum seekers appears to be driven principally by protracted instability and conflict in regions of origin", ${ }^{26}$ as well as the absence of emergencies on the EU's borders giving rise to large numbers of refugees and stabilising measures in countries that produced large refugee flows in the early part of the century.

Restrictive measures such as visa requirements, carrier sanctions and the stationing of immigration liaison officers at foreign airports for pre-entry clearance before departure have become a routine means of preventing asylum seekers from arriving in Member States' territories, and, in effect, hampering asylum seekers from ever leaving their own countries. ${ }^{27}$ Since 1999, "the EU has invested millions of Euros increasing the number of border guards, strengthening maritime surveillance, using helicopters and surveillance equipment such as infra-red detection devices, exploring the use of satellites to detect persons crossing borders, and using biometric and fingerprinting equipment."28 The first phase of the Common European Asylum System has similarly highlighted "a creeping confusion between 'asylum' and 'immigration' procedures", distorting protection to serve migration control strategies. ${ }^{29}$ The drawbridge of Fortress Europe is closing.

The decision to devise a Common European Asylum System was welcomed as an attempt to harmonise inconsistent practices relating to the admission and status of persons seeking asylum in the EU. On the other hand, however, it has been criticised for failing to address asylum from a protection-oriented perspective. Instead, critics have pointed to a securitarian agenda that fuses asylum with immigration control, and has an underlying obsession with "numbers" and reducing "bogus" asylum claims. ${ }^{30}$

25 United Nations High Commissioner for Refugees (UNHCR) The State of the World's Refugees: Human Displacement in the New Millennium (Oxford University Press, Oxford, 2006) 14.

26 Ibid, 17

27 See $R$ v Immigration Officer at Prague Airport, ex $p$ European Roma Rights Centre [2004] UKHL 55; Geoff Gilbert "Is Europe Living up to its Obligations to Refugees?" (2004) 15 European Journal of International Law 963, 971-72.

28 European Council Refugees and Exiles (ECRE) "Broken Promises - Forgotten Principles: An ECRE Evaluation of the Development of EU Minimum Standards for Refugee Protection, Tampere 1999-Brussels 2004" 15 www.ecre.org (accessed 1 April 2007).

29 Bouteillet-Paquet, above $\mathrm{n} 24$.

30 See Sandra Lavenex "The Europeanisation of Refugee Policies: Normative Challenges and Institutional Legacies" (2001) 39 Journal of Common Market Studies 851; Gilbert, above n 27, 963. 
Immigration law is about controlling entry to territory in order to preserve a particularistic community. ${ }^{31}$ From a legal perspective, it may legitimately take as its starting point demographic and economic concerns. By contrast, refugee law is about international protection. ${ }^{32}$ International protection is not a migration tool, but a legal duty grounded in States' obligations under international human rights and refugee law, which also has a strong underlying ethical basis. ${ }^{33}$ In contemporary practice, it recognises that where one State fails to secure certain rights for its nationals, other States will provide substitute protection. International protection has become, however, one of the most contested political issues of the past decade, and a trump card that has been repeatedly played by politicians all over the world. ${ }^{34}$ This strategy relies on fear of "the other", exaggerates and manipulates cultural and religious differences, and makes scapegoats of asylum seekers for taking jobs and, more recently, for committing terrorist acts. ${ }^{35}$ Protection encapsulates the "formidable conflict between the State's prerogative to exclude and the human rights imperative to include." ${ }^{36}$ It lies in the "conflict zone" between universalism (prioritising universal human rights) and particularism (preferencing the interests of a particular State's population). ${ }^{37}$

This plays out in a particularly interesting manner in the EU, a zone of "free movement" across 27 countries. The relaxation of internal border controls has led to an intense focus on the EU's external borders, ${ }^{38}$ coupled with concerns about redistributing the "burden" of refugees among the EU States. As Noll and Vedsted-Hansen have observed, an Orwellian paradox emerges as the EU integrates further, since "integration is attained by means of exclusion, freedom achieved by means of control." 39 As internal borders dissolve, external borders rise. ${ }^{40}$

31 Noll and Vedsted-Hansen, above n 16, 363.

32 This is the starting point of Gilbert's thesis, above $n$ 27, 968.

33 As Michael Walzer has argued, while States are generally able to determine entrance policies according to their own criteria, in the case of refugees, they are bound by the principle of mutual aid and are morally bound to take in as many refugees as they can without disturbing the State's "way of life": Michael Walzer Spheres of Justice: A Defense of Pluralism and Equality (Martin Robertson, Oxford, 1983). Gibney calls this the principle of humanitarianism: Gibney, above n 18, 233.

34 See for example the way in which the Australian government manipulated the Tampa incident during its election campaign in 2001, and the US government's linkages of asylum seekers and terrorists post-9/11. For a discussion of Australian and UK examples, see Colville, above n 23, 14.

35 See generally articles in (2006) 142 Refugees.

36 Noll and Vedsted-Hansen, above n 16, 364.

37 Ibid, 360

38 On this point, see ibid, 361.

39 Ibid, 362.

40 Although as this paper will explore, it is interesting to see how nationals of the new Member States have been treated with respect to asylum claims. 
At the same time, although much harder to demonstrate empirically, is a feeling that the citizens of Member States (some more strongly than others) are staunchly guarding their own national traditions and identities, even if they recognise the advantages of being part of a strong alliance of States. ${ }^{41}$ Some evidence of this can be gleaned from the "Eurobarometer" surveys carried out in Member States twice a year. ${ }^{42}$ "Immigration" was considered as one of the two most important issues facing the EU by 13-15\% of those surveyed between Autumn 2004 and Spring 2005, ranking similarly to "Terrorism" and "Healthcare", but was considerably less important than "Unemployment", "Economic Situation" and "Crime". Support for membership of the EU declined from $54 \%$ to $50 \%$ in the same period, having fluctuated in the 10 years from 1995-2005 from a low of $46 \%$ in Spring 1997 to a high of 56\% in Spring 1995 and Autumn 2004.

While the EU is in some respects State-like, it is not patrie-like. There is a sense that it is an artificial construct which lacks a genuine demos, while simultaneously creating rights that necessarily constrain the individual sovereignty of its members. While the absence of a regional identity could work to the advantage of those seeking to promote international law as the foundation for EC agreements, it is instead usurped by the invocation of 27 national ones, each infused with "a mythical quality, which moves the concrete balance [between inclusion and exclusion] out of the reach of rational discourse."43 There is no "EU identity" capable of competing with national counterparts. ${ }^{44}$ Perhaps the EU's identity is so fraught precisely because its citizens imagine it through "a plurality of national lenses."45 Created primarily as a mechanism for economic integration, it has so far failed to create a legitimate social and political character with which its "citizens" can identify. ${ }^{46}$

41 Note the failure of referenda in France and the Netherlands for those States to ratify the Treaty establishing a Constitution for Europe, and the Eurobarometer statistics discussed in the text below on support for EU membership. Of course, one must be careful in referring to $a$ national identity: nations have a plurality of identities and sub-cultures which cannot be reduced to a single, perceptible idea.

42 Each survey consists of around 1000 face-to-face interviews in each Member State, with the exception of Germany (2000 interviews), Luxembourg (600 interviews) and the UK (1300 interviews, including 300 in Northern Ireland). See http://ec.europa.eu (accessed 1 April 2007). Note thematic compilations on "national versus European identity".

43 Noll and Vedsted-Hansen, above n 16, 361.

44 Ibid

45 Vivien Schmidt "Democratic Challenges for the EU as 'Regional State"' (2004) 17 European Union Studies Association Review 3, 3. Leino points out: "Even if most EU citizens agree on the enumeration of human rights in general, they disagree on what those rights contribute to political and social practice": Päivi Leino "A European Approach to Human Rights? Universality Explored" (2002) 71 Nordic Journal of International Law 455, 456.

46 Noll and Vedsted-Hansen, above n 16, 361. 
Seen from the perspective of the Member States, the Union is about sharing protection with the populations of other Member States. Seen from the outside, the Union appears as a merger of mighty sovereigns promoting protection for its populations at the expense of others. Extending protection means giving up the established link between a preconceived demos and inclusion. Limiting protection begs the double question of where to draw the line and how to justify it.

Thus, ironically, rather than fostering pan-European sentiments in the average German or Pole, membership of the EU may, in certain sectors, encourage insularism and heighten fears of national identity loss. If the community of a Member State already feels marginalised by membership, this may foster an instinct both to exclude others (who may be perceived as threatening the national status quo even further) and to make sure that within the supranational regime, one's own State is not "burdened" by more than its "fair share" of refugees. In other words, it may inspire a double deflection mentality.

Such sentiments are rather ephemeral and hard to measure. Nonetheless, they are perceptions that feed into and from ${ }^{47}$ political debates about identity politics, inclusion and exclusion, responsibilities and burdens. By virtue of the EU system, national governments go to the European institutions with domestic political concerns in mind, and accordingly these come to bear on EU law.

It is somewhat of a "chicken or egg" question whether national representatives at the EU level are simply responding to local concerns in bringing such attitudes to the supranational table, or whether the power of supranational instruments and institutions form a useful shield to legitimise restrictive actions. At the national level, EC law may provide a useful tool for Eurosceptics and Communitarians alike. Laws that are unpopular among voters may be blamed on EU requirements, while populist (restrictive) laws that are opposed on human rights or other grounds may obtain a certain legitimacy if endorsed at the EU level. For example, the German government, keen to limit the right to constitutional asylum by introducing "safe third country" rules, ${ }^{48}$ drove proposals at the EU level to develop agreements by which Member States would return asylum seekers to the EU State which they first entered. "The opaque nature of transgovernmental co-operation strengthened their domestic position, enabling them to present European agreements to their national parliaments as faits accomplis and to frame domestic concerns in terms of European integration." ${ }^{4}$ This example illustrates how partisan national actors may subvert domestic opposition by shaping EU

47 See Gibney, above n 18, on this point.

48 These are rules to determine when a country through which an individual has transited is sufficiently safe for the individual to be returned there. That country must have sufficient refugee status determination procedures and be able to provide "effective protection".

49 Lavenex, above n 30, 862. 
policies, thus providing "the normative context for the consent of the pro-European opposition" 50 and the courts. ${ }^{51}$ In other words, the EU imprimatur can function as a legitimating force.

\section{FROM THE NATIONAL TO THE REGIONAL}

Unlike UNHCR and the Council of Europe, both of which have a mandate to protect refugees and human rights, the EU was established predominantly as an economic organisation. By contrast to the international protection regime, asylum at the EU level was driven not by a focus on universal human rights, but "as a side issue of the single market project, with co-operation occurring only insofar as it was deemed necessary to safeguard internal security." 52

Until 1986, asylum and immigration policy remained in the domain of individual Member States. The passage of the Single European Act in 1986, which sought to create a European "space" free of internal border controls to realize the free movement of goods, workers, services and capital, precipitated certain transgovernmental consultations on the asylum question. It was not until the entry into force of the Maastricht Treaty in November 1993 that the issue transformed into one of "common concern". However, common positions on asylum remained relatively under-developed, since asylum remained in a transnational law-making structure based on inter-governmental cooperation, rather than at the level of binding EC competence. ${ }^{53}$

On 1 May 1999, the Treaty of Amsterdam conferred competence on the EC, shifting immigration and asylum issues to the First Pillar of the EU. This was a significant change, since it signalled Member States' relinquishment of their sovereign right to develop national asylum policies in favour of a common regional approach that would bind them under EC law. It was considered that the European Commission could take an approach "more comprehensive and less driven by State self-interest", with supranational judicial controls providing "a positive restraining force". ${ }^{54}$ However, though asylum and immigration became subject to the EU's supranational structure and thus to the domain of EC legislative and institutional competence, Member States insisted on certain controls. In an unanticipated move, they retained a veto power for the first five years; determined that the European Parliament's opinions and amendments relating to draft laws need not be

$50 \quad$ Ibid.

51 See, for example, German Federal Constitutional Court BverGE 2 BvR 1938/93 and 2 BvR $2315 / 93$ (14 May 1996) para 1, cited in ibid.

52 Lavenex, above n 30, 860 .

53 At this time, asylum and immigration were in the Third Pillar of the EU, which meant they were outside EC competence.

54 ECRE "Analysis of the Treaty of Amsterdam in so far as it relates to Asylum Policy" (updated 10 November 1997) www.ecre.org (accessed 1 January 2007) 2. 
followed; ${ }^{55}$ and limited the competence of the European Court of Justice to preliminary rulings on matters of interpretation, and only when sought by a national court. ${ }^{56}$ This considerable retention of national control led some commentators to describe the movement of asylum matters to the First Pillar as a "technical transfer" only, enabling instruments of harmonisation to be developed by the Council of Ministers "without the correspondingly forceful democratic and judicial controls over that process that are in place in other areas of EC law."57 It gives EC "authority" to matters that remain heavily influenced by domestic political concerns, but which are dressed up as supranational instruments.

It was in this context that the Common European Asylum System was devised. ${ }^{58}$ Its rationale is explained by the European Commission as follows: ${ }^{59}$

The European Union (EU) is an area in which freedom of movement must be ensured. Since the beginning of $1990 \mathrm{~s}$, the flow of persons seeking international protection in the EU has been such that the Member States have decided to find common solutions to this challenge. A set of commonly agreed principles at European Community level in the field of asylum can provide a clear added value while continuing to safeguard Europe's humanist tradition.

According to Lavenex, however, the real aim of the Common European Asylum System (CEAS) is "to reduce immigration pressure and to compensate for the perceived losses of internal security in the wake of the full freedom of movement inside the Union."60 Nonetheless, it is significant - not least in assessing its success - that the Tampere Conclusions of 1999, which introduced the first phase of the CEAS, noted that legislation was to be based on the "full and inclusive application of the Geneva Convention"61 and a "shared commitment to ... human rights". 62

55 This is very different from the Parliament's role in other First Pillar areas, where it may amend or veto proposed measures: contrast Treaty on European Union (7 February 1992) OJ C340 [TEU].art 67 with art 251

56 Ibid, art 68.

57 ECRE, above n 54, 2.

58 The first phase was set out in the Tampere Conclusions of 1999 (Presidency Conclusions Tampere European Council 15-16 October 1999, SN 200/99); the second phase is described by the Hague Programme of 2005 (adopted 5 November 2004).

59 European Commission "The European Union Policy towards a Common European Asylum System" (updated February 2006) http://ec.europa.eu/justice_home (accessed 1 January 2007).

60 Lavenex, above n 30, 868.

61 Tampere Conclusions, above n 58, para 13.

62 Ibid, para 1. 


\section{THE EUROPEAN" REFUGEE" CONCEPT}

On 29 April 2004, the Member States adopted the "Qualification Directive" as one of the first CEAS instruments. Its purpose is to provide minimum standards for the qualification and status of third country nationals or stateless persons as refugees, or as persons who otherwise need international protection, and the content of the protection granted. National laws had to comply with it by 10 October 2006. ${ }^{63}$ The Directive is based on pre-existing Member State practice, and aims simply to harmonise existing concepts by drawing on the "best" elements of the Member States' national systems. ${ }^{64}$ It is therefore not intended as a radical overhaul of protection, but as a codification of existing State practice. While this approach evidences a pragmatic response to the political realities of the EU and the need to create an instrument of compromise, it also means that the Directive is not a result of a comprehensive and systematic analysis of all protection possibilities within international law. Furthermore, it is probable that the Directive will not lead to more people being granted protection in the $\mathrm{EU}^{65}$ because it is based on a restrictive interpretation of existing practices rather than a new regime.

\section{A Legal Consequences}

The Directive's definition of a "refugee"66 is substantively identical to article $1 \mathrm{~A}(2)$ of the Refugee Convention with one significant exception: it applies only to third country nationals and stateless persons. ${ }^{67}$ This has drawn sharp criticism from UNHCR and other commentators, ${ }^{68}$ who

63 The Directive does not apply to Denmark, in accordance with articles 1 and 2 of the Protocol on the Position of Denmark annexed to the Treaty on European Union [2002] OJ C325/5 and the TEC, above n 4: Qualification Directive, above n 2, recital 40.

64 "Explanatory Memorandum" in Commission of the European Communities "Proposal for a Council Directive on Minimum Standards for the Qualification and Status of Third Country Nationals and Stateless Persons as Refugees or as Persons Who Otherwise Need International Protection" COM (2001) 510 final (12 September 2001) 5. Note that it was drafted prior to the 1 May 2004 enlargement of the EU and hence relied on the State practice of the 15 Member States at that time.

65 Thomas Spijkerboer "Subsidiarity in Asylum Law: The Personal Scope of International Protection" in Daphné Bouteillet-Paquet (ed) Subsidiary Protection of Refugees in the European Union: Complementing the Geneva Convention? (Bruylant, Brussels, 2002) 39.

66 Qualification Directive, above n 2, art 2(c).

67 Based on TEC, above n 4, art 63 and Protocol on Asylum for Nationals of Member States of the European Union (Protocol 29).

68 UNHCR's Observations on the European Commission's Proposal for a Council Directive on Minimum Standards for the Qualification and Status of Third Country Nationals and Stateless Persons as Refugees or as Persons Who Otherwise Need International Protection" 14109/01 ASILE 54 (16 November 2001) para 11; Amnesty International EU Office "Amnesty International's Comments on the Commission's Proposal for a Council Directive on Minimum Standards for the Qualification and Status of Third Country National [sic] and Stateless Persons as Refugees or as Persons Who Are Otherwise in Need of International Protection COM (2001) 510 final" (2 October 2002) www.amnesty-eu.org (accessed 1 January 2007) 2; European 
rightly argue that imposing such a restriction on the definition of a "refugee" contravenes article 42 of the Refugee Convention, which prohibits States from limiting the personal scope of article 1 (the refugee "definition") or making reservations to article 3 (non-discrimination on grounds of country of origin) ${ }^{69}$

The restrictive approach was derived from the terms of the Treaty of Amsterdam, which, as incorporated in the TEC, limits the personal scope of the EC asylum instruments to third country nationals. ${ }^{70}$ However, the TEC also states that EC asylum legislation must be "in accordance with the Geneva Convention of 28 July 1951 and the Protocol of 31 January 1967 relating to the status of refugees and other relevant treaties". ${ }^{71}$ In other words, the EC, in addition to Member States, must be guided by their provisions. ${ }^{72}$ Given that Member States must take steps to eliminate any inconsistencies between EC law and international law, including by denouncing incompatible international treaties, ${ }^{73}$ the express reference to States' international legal obligations here is significant.

The EU/EC is not itself bound by international human rights treaty law and there is currently no legal basis on which it can be. ${ }^{74}$ Article 307 TEC regulates the relationship between EC law and international treaties entered into by Member States prior to the TEC. ${ }^{75}$ Any conflicts between EC law and pre-existing international treaty obligations must be resolved in favour of the latter. Thus, Member States' obligations under the 1951 Refugee Convention and its 1967 Protocol, the International Covenant on Civil and Political Rights, the International Covenant on Economic,

Parliament "Report on the Proposal for a Council Directive on Minimum Standards for the Qualification and Status of Third Country Nationals and Stateless Persons as Refugees or as Persons Who Otherwise Need International Protection, Explanatory Statement" PE 319.971 (8 October 2002) 53; House of Lords Select Committee on the European Union Defining Refugee Status and Those in Need of International Protection (The Stationery Office, London, 2002) para 54. Although not formally a party to the negotiations, UNHCR maintained a close interest in the development of the Directive since it goes to the heart of its own mandate.

Recital 11 of the Qualification Directive, above n 2, limits non-discrimination to persons covered by the instrument.

70 TEC, above n 4, art 63.

71 Ibid.

72 Frances Nicholson "Challenges to Forging a Common European Asylum System in Line with International Obligations" in Steve Peers and Nicola Rogers (eds) EU Immigration and Asylum Law: Text and Commentary (Martinus Nijhoff Publishers, Leiden, 2006) 514. Nicholson also notes that under article 6(2) of the TEU, above $\mathrm{n} 55$, the EU must also respect fundamental rights guaranteed by the ECHR.

73 Case C-62/98 Commission v Portugal [2000] ECR I-5171, para 49, and Case C-84/98 Commission v Portugal [2000] ECR I-5215, para 58.

74 Bosphorus Hava Yollari Turism ve Ticaret Anonim Şirketi v Ireland (2006) 42 EHRR 1, para 152. On this point, see Costello, above n 15, 87; Guild, above n 15.

75 Note that each Member State has different obligations depending on when each joined the EU. 
Social and Cultural Rights, the Convention against Torture and Other Cruel, Inhuman or Degrading Treatment or Punishment and the Convention on the Rights of the Child all take precedence over EC Directives. However, article 307(2) requires Member States to take steps to eliminate any inconsistencies between EC and international law, and the only means to do this may be by denouncing the international instrument. ${ }^{76}$ This, of course, would require consideration of articles 54 and 56 of the Vienna Convention on the Law of Treaties which set out the circumstances in which denunciation is permissible. ${ }^{77}$ Article $60(5)$ of that treaty states that "provisions relating to the protection of the human person contained in treaties of a humanitarian character" may not be terminated by one party or some parties to that instrument. ${ }^{78}$ Were this not the case, then it would render the pre-eminent place of pre-existing treaties under the TEC futile and would create inconsistencies for States that acceded to the relevant treaties after the TEC's entry into force or after accession. ${ }^{79}$

In the context of asylum law, Peers argues that article 63(1) TEC may be viewed as lex specialis to article 307 TEC. ${ }^{80}$ Gil-Bazo has gone on to suggest "that therefore if EC asylum law required Member States to violate their obligations under international refugee and human rights law, the relevant EC law would be invalid without a further obligation on Member States to denounce the said treaties." ${ }^{81}$ As Storey points out, no such denunciation has taken place, and he queries whether two different refugee regimes must therefore necessarily operate in the EU from 10 October 2006 (the date by which the Member States have to implement the Qualification Directive) ${ }^{82}$ - one based on the Qualification Directive for third country nationals, and one based on the international refugee

76 Case C-62/98, above n 73, para 49, and Case C-84/98, above n 73, para 58; Jan Klabbers "Moribund on the Fourth of July? The Court of Justice on Prior Agreements of the Member States" (2001) 26 European Law Review 196.

77 Pietro Mansini "The Priority of Pre-Existing Treaties of EC Member States within the Framework of International Law" (2001) 12 European Journal of International Law 791.

78 This is pointed out by Nicholson, above $\mathrm{n} 72,526$.

79 Mansini, above n 77. Case C-203/03 Commission v Austria, judgment of the Court 1 February 2005, paras 61-64, not yet reported. These arguments rely on María-Teresa Gil-Bazo "Refugee Status, Subsidiary Protection, and the Right to Be Granted Asylum under EC Law" UNHCR New Issues in Refugee Research, Research Paper No 136 (November 2006) 3-5.

80 Steve Peers "Human Rights, Asylum and Community Law" (2005) 24(2) Refugee Survey Quarterly 24.

81 Gil-Bazo, above n 79, 5. However, as she notes, this only applies to legislation based on article 63(1). For legislation based on articles 63(2) or (3), which is the domain of subsidiary protection, this compliance matrix does not prima facie apply. Nevertheless, human rights are considered general principles of Community law, and all Community legislation must comply with those principles.

82 H Storey "The Refugee Qualifications Directive: An Introduction" (Asylum and Immigration Tribunal Training, Spring 2006) (draft paper in author's possession). 
law regime. ${ }^{83}$ What this will mean in practice, and in terms of legal status, is unclear. Under the Refugee Convention, Member States are obliged to provide a particular status to "refugees". This is reflected in, but in some respects extended by, the Qualification Directive. Are refugees who are also EU nationals to be granted an identical status? If not, how is a lesser status to be justified in light of article 3 of the Refugee Convention, which prohibits discrimination between refugees on the basis of their country of origin? If EU Member States are to abide by their international law obligations, then the international law requirement to accord refugees an identical status necessarily renders the Qualification Directive's exclusion of EU nationals ineffective. This strengthens the argument that the Qualification Directive is largely about political appearances. ${ }^{84}$ It also highlights the inexact status of citizenship at the EU level. While the EU ideal is a region in which legal rights and status are identical for all citizens, if in reality certain citizens lack protection, then may they claim refugee status in other parts of that region?

\section{B Practical Consequences}

The Qualification Directive's restrictive interpretation of the refugee definition has a regional precursor: the 1997 Protocol on Asylum for Nationals of Member States of the European Union. ${ }^{85}$ This provides (with limited exceptions ${ }^{86}$ ) that:

Given the level of protection of fundamental rights and freedoms by the Member States of the European

Union, Member States shall be regarded as constituting safe countries of origin in respect of each other for all legal and practical purposes in relation to asylum matters.

The Protocol was a political response by Spain to the protection which Belgium and France had granted to members of the Basque separatist movement ETA. ${ }^{87}$ Spain considered it "illogical" that

83 Is the Qualification Directive regime to operate with respect to EU nationals, since it is said to be without prejudice to the 1997 Protocol (recital 11)? How does this work when EU nationals are defined out of it, though?

84 See Costello, above n 15, 87; Guild, above n 15, 122-23.

85 For criticism of it at the time of drafting, see UNHCR "UNHCR's Position on the Proposal of the European Council concerning the Treatment of Asylum Applications from Citizens of European Union Member States" (January 1997); K Landgren "Deflecting International Protection by Treaty: Bilateral and Multilateral Accords on Extradition, Readmission and the Inadmissibility of Asylum Requests" UNHCR New Issues in Refugee Research, Working Paper No 10 (June 1999); N Sitaropoulos "Entwurf einer 'EUAnerkennungs-Richtlinie"' (2003) 23 Zeitschrift für Ausländerrecht und Ausländerpolitik 379.

86 Exceptions are if the country of origin has formally derogated from parts of the ECHR; if the Council has determined (or is seized with but has not yet determined) "the existence of a serious and persistent breach" of human rights; or if a Member State unilaterally chooses to examine the asylum claim, in which case it "shall be dealt with on the basis of the presumption that it is manifestly unfounded".

87 Landgren, above $\mathrm{n} \mathrm{85,8}$. States did not agree to its original proposal to remove entirely the right of a Member State to process an asylum claim by an EU national: "Every citizen of the Union shall be regarded, for all legal and judicial purposes connected with the granting of refugee status and matters relating to 
EU nationals might need to seek asylum in another EU Member State, since all Member States are democratic, abide by the rule of law and are committed to the observance of human rights. ${ }^{88}$ Thus, the rationale behind this and the Qualification Directive's "third country nationals" provision is that the level of human rights protection in the EU has reached such a level that all Member States should be considered as safe countries of origin. Yet, as UNHCR has observed: ${ }^{89}$

It is impossible, realistically speaking, to exclude the possibility that an individual could have a well-

founded fear of persecution in any particular country, however great its attachment to human rights and

the rule of law. While a highly sophisticated democratic order and an elaborate system of legal

safeguards, as well as of judicial and administrative remedies, allow for a general presumption of safety,

the need for international protection cannot be excluded absolutely and categorically in every case. Nor,

regrettably, can fundamental changes in the political system or in the human rights situation of any

State.

Indeed, despite the EU's commitment to human rights, the European Court of Human Rights still receives thousands of complaints each year against Member States, many of which are deemed admissible. ${ }^{90}$ Both the Protocol and the Qualification Directive are based on the false assumption that persecution (or torture, inhuman or degrading treatment or punishment) can stem only from a pattern of human rights abuses, when it may in fact occur from-and warrant international protection as a result of - an isolated act.

Furthermore, the argument goes, EU nationals need not seek asylum in another Member State, since they enjoy EU "citizenship rights" which ensure a level of protection similar to that provided by the 1951 Convention. ${ }^{91}$ However, though EU law is supposed to apply equally across all Member States: ${ }^{92}$

asylum, as a national of the Member State in which he is seeking asylum. Consequently, no State of the Union shall agree to process an application for asylum submitted by a national of another State of the Union": Conference of the Representatives of the Governments of the Member States "Discussion Paper" (Brussels 4 February 1997) SN/507/97 (C 8) para 1, cited in Landgren, above n 85, 8. Belgium made a Declaration to the Protocol that it would continue to "carry out an individual examination of any asylum request made by a national of another Member State." See also Guy S Goodwin-Gill "The Individual Refugee, the 1951 Convention and the Treaty of Amsterdam" in Elspeth Guild and Carol Harlow (eds) Implementing Amsterdam: Immigration and Asylum Rights in EC Law (Hart Publishing, Oxford, 2001) 153-55 and citations referred to in Nicholson, above n 72, 515, n 44.

88 Memorandum espagnol sur la non-reconnaissance du droit d'asile pour les citoyens de l'Union (Brussels 24 February 1997) CONF/3826/97 ANNEXE, cited in Landgren, above n 85, 11

89 UNHCR, above n 85, para 3.

90 In 2005, 1000 claims were declared admissible, with 26,852 declared inadmissible: European Court of Human Rights "Survey of Activities 2005" www.echr.coe.int (accessed 1 March 2007) 32.

91 Discussed in UNHCR "Towards a Common European Asylum System" in Costança Dias Urbano de Sousa and Phillipe de Bruycker The Emergence of a European Asylum Policy (Bruylant, Brussels, 2004) 231. 
as the case of the Roma illustrates there are occasions when even if there are supposedly safeguards in place in theory, those safeguards are not being effectively implemented and for the individuals concerned, regardless of membership of the club, they are being persecuted in their country and they are not being protected and that is what the courts here [UK], and indeed the authorities in other countries, have found in over 7,000 cases.

Finally, even if the "third country national" limitation has little effect in practice on refugee recognition statistics, it is undesirable that EU States set an example of limiting the application of the Convention definition in this way and undermining international law through a tailored regional agreement. ${ }^{93}$ According to UNHCR, "what is at issue here is the universal applicability of the provisions of the 1951 Convention and its 1967 Protocol without a geographical limitation."94 Similarly, as the House of Lords Select Committee on the EU has noted, "for a major regional grouping of countries such as the Union to adopt a regime apparently limiting the scope of the Geneva Convention among themselves would set a most undesirable precedent in the wider international/global context."15

\section{EU ASYLUM SEEKERS AND THE RIGHT TO FREE MOVEMENT}

What rights, then, do EU nationals have to relocate to another part of the region if they fear persecution or ill-treatment in their own country? While freedom of movement is a basic tenet of the EU, there is not yet an equal right to free movement for all EU nationals. In any case, freedom of movement does not equate to an unconditional right of residence. Those affected by the EU's restricted asylum laws are also those most likely to be affected by the limitations on freedom of movement, as the example of the Roma illustrates.

This was the line of argument presented to the author by Richard Lewis, Former Deputy Head of the Immigration and Asylum Unit, European Commission (Asylum and Migration: Policy and Practice in the EU Accession Countries Conference, Prague, 5-6 June 2004).

92 House of Lords Select Committee on the EU Defining Refugee Status and Those in Need of International Protection (The Stationery Office, London, 2002) para 50 (Mr Hardwick, Refugee Council).

93 This echoes Protocol 29 to the TEC on Asylum for Nationals of Member States of the European Union..

94 UNHCR "Towards a Common European Asylum System", above n 91, 232.

95 House of Lords Select Committee on the EU, above n 92, para 54. See also comments of UNHCR at para 52 of that report. Although the Convention and human rights treaties would still apply to EU citizens, their resultant legal status would be uncertain. Additionally, the argument that EU citizens may in any case move freely within the EU does not justify the breach of international law in the Directive, nor does such freedom of movement necessarily guarantee an equivalent level of rights as provided for in the Directive, especially for citizens of the new Member States. When the same concern was raised with respect to the 1997 Protocol, some EU delegations argued that "the stage of development and the level of respect for human rights were clearly different in the European Union states from states in other regional organisations, and therefore no other region could make the same case for doing away with asylum": Internal UNHCR Note (meeting of 13 February 1997), cited in Landgren, above n 85, 12, n 42. 
There is no exact numerical data on Roma (commonly described as "gypsies"), so figures are estimates based on population censuses and NGOs. The Minority Rights Group, for example, estimates between 908,000 and 1.49 million Roma became EU citizens on 1 May 2004. ${ }^{96}$ Between 1997 and 2005, around 12,000 to 15,000 Roma sought asylum in the EU, Switzerland, Norway and Canada. Many were unsuccessful in receiving protection as Convention refugees, since it was believed that they had fled from "safe countries". ${ }^{97}$ Nonetheless, their plight as a discriminated minority is well-documented. ${ }^{98}$

While discrimination is not necessarily "persecution" for a Convention reason, in some instances Roma may qualify as refugees in accordance with the definition in article $1 \mathrm{~A}(2)$ of the Refugee Convention. ${ }^{99}$ It is not possible to determine the exact number of Roma who have been recognised as Convention refugees, since refugee data is not compiled on the basis of ethnicity. However, between 1990-99, 7232 persons from States with a high Roma population (Bulgaria, the Czech Republic, Hungary, Poland, Romania and the Slovak Republic - all but Bulgaria and Romania are now EU Member States) were granted Convention refugee status, with a further 3300 granted some form of humanitarian status. ${ }^{100}$ These numbers are not inconsiderable.

96 Referred to in Karin Waringo "Who is Afraid of Migrating Roma?" in (Un)Freedom of Movement: Migration Issues in Europe (2004) (Eumap.org Online Journal) www.eumap.org (accessed 5 March 2007). According to Tanner, when Romania and Bulgaria accede to the EU in 2007, a further 2.5 million will become EU citizens: Arno Tanner "The Roma of Eastern Europe: Still Searching for Inclusion" (Migration Policy Institute, Washington, 2005).

97 Tanner, above n 96

98 In 2003, the UN Committee on the Elimination of Racial Discrimination expressed concerns about "the continuance of acts of racially motivated violence and incitement to hatred and the persistence of intolerance and de facto discrimination, in particular with regard to the Roma minority"; "allegations of racially motivated ill-treatment, ineffective protection and discrimination against the Roma by law enforcement officials, especially the police"; the "disproportionately high" unemployment rate among Roma; "the evictions from flats or threats to evict reportedly faced by many Roma families"; and "the continued placement of a disproportionately high number of Roma children in 'special schools'": Concluding Observations of the Committee on the Elimination of Racial Discrimination: Czech Republic (10 December 2003) CERD/C/63/CO/4 paras 9, 11, 12, 13, 14 respectively. See also UN Committee on the Elimination of Racial Discrimination "General Recommendation XXVII: Discrimination against Roma" (57 ${ }^{\text {th }}$ session 16 August 2000); Lori Sachs "Roma: Five Centuries of Discrimination ... and Still Counting" (1999) 113 Refugees. For concerns about anti-Semitism in Poland, see: $R$ (on the Application of Bodsek) $v$ Special Adjudicator [2002] EWHC 1525 (Admin). On the UK's discrimination of Roma in pre-entry clearance procedures at Prague Airport, see $R v$ Immigration Officer at Prague Airport, ex $p$ European Roma Rights Centre [2004] UKHL 55.

99 See for example UNHCR Roma Asylum-Seekers, Refugees and Internally Displaced (UNHCR, Geneva, October 2000) paras 7-10.

100 Ibid, 16 
Prior to accession, the candidate countries were pressured by existing Member States to improve the situation of their ethnic minorities as a prerequisite to entry into the EU. At the time, some suspected that these concerns did not stem purely from humanitarian impulses, but rather were driven by self-interest: "[s]weeping restrictions of the freedom of movement and populist reactions in some countries have now shown that the Union of 15 did not feel entirely comfortable with the idea of having over a million more Roma among its population."101 An analysis of the combined effect of the Qualification Directive and restrictions on freedom of movement and residence shows that the ability of groups (such as the Roma) to relocate is appreciably circumscribed.

All EU citizens with an identity card or passport have the right to enter another Member State, which means that an asylum seeker from one EU country may freely enter another. This in itself may pose a barrier for Roma. For example, there is evidence that many Roma living in Russia (though not a Member State) have found the cost of travelling to St Petersburg or Moscow to obtain a passport prohibitive, and accordingly have not attempted to apply for one. ${ }^{102}$ Even if individuals have the requisite documents to enter another Member State, they may only reside there for three months, unless they: ${ }^{103}$

(a) are workers or self-employed persons in the host Member State; or

(b) have sufficient resources for themselves and their family members not to become a burden on the social assistance system of the host Member State during their period of residence and have comprehensive sickness insurance cover in the host Member State; or

(c) - are enrolled at a private or public establishment, accredited or financed by the host Member State on the basis of its legislation or administrative practice, for the principal purpose of following a course of study, including vocational training; and

- have comprehensive sickness insurance cover in the host Member State and assure the relevant national authority, by means of a declaration or by such equivalent means as they may choose, that they have sufficient resources for themselves and their family members not to become a burden on the social assistance system of the host Member State during their period of residence; or

101 Waringo, above n 96 (citations omitted). Waringo refers, for example, to the anti-Roma campaign by Heinz-Christian Strache of the Austrian FPÖ: "FPÖ-Strache warnt vor 'Roma-Ansturm' auf Wien" (6 May 2004) Der Standard http://derstandard.at (accessed 1 March 2007).

102 Leonid Raihman Roma in Russia: A Personal Documents Disaster (European Roma Rights Center, Budapest, 2003) www.errc.org (accessed 1 March 2007).

103 Council Directive 2004/38/EC (29 April 2004) on the Right of Citizens of the Union and Their Family Members to Move and Reside Freely within the Territory of the Member States amending Regulation (EEC) No 1612/68 and Repealing Directives 64/221/EEC, 68/360/EEC, 72/194/EEC, 73/148/EEC, 75/34/EEC, 75/35/EEC, 90/364/EEC, 90/365/EEC and 93/96/EEC [2004] OJ L158/77 art 7. 
(d) are family members accompanying or joining a Union citizen who satisfies the conditions referred to in points (a), (b) or (c).

EU citizens only obtain the right of permanent residence in the host Member State once they have resided there for an uninterrupted period of five years (provided that they have not had an expulsion decision enforced against them). ${ }^{104}$ This is forfeited if an individual spends more than two successive years outside the Member State. Until permanent residence has been granted, host States are not obliged to provide social security entitlements to anyone other than workers and their family members, or to provide maintenance grants to students.

These conditions immediately disqualify most Roma from moving to another Member State. The majority lack self-sufficiency to survive without a job; labour restrictions may preclude them from being eligible for employment; and even where labour restrictions are not in place, it may be difficult for Roma to obtain work. ${ }^{105}$

\section{RESTRICTIONS}

Due to fears by the existing 15 Member States that, given the weaker eastern European economies, nationals from those acceding countries might be encouraged to migrate in search of employment, the Accession Treaty enabled the 15 Member States to introduce "transitional measures" restricting employment-related migration (that is, movement of "migrant workers") from the new Member States for up to seven years from the date of accession (1 May 2004). ${ }^{106}$

104 For exemptions, see art 17. Expulsion may be ordered on grounds of public policy, public security or public health, where there is a sufficiently serious and present threat affecting the State's fundamental interests, but must not be ordered not for economic reasons. Factors such as age, integration, family ties and links with the home State must be considered. Orders may be reviewed after three years.

105 Entrenched discrimination may mean that many lack a level of education equivalent to other nationals of their home State: see evidence in DH v Czech Republic App No 57325/00 (7 February 2006); European Roma Rights Center Stigmata: Segregated Schooling of Roma in Central and Eastern Europe, A Survey of Patterns of Segregated Education of Roma in Bulgaria, the Czech Republic, Hungary, Romania, and Slovakia (European Roma Rights Centre, Budapest, 2004). Official data for the 3rd quarter of 2003 indicated that approximately $87.5 \%$ of the Slovak Romani population was unemployed during the period, by contrast to an unemployment rate of $14.2 \%$ for the population as a whole: Claude Cahn "The Last Europeans: Roma on the Eve of Enlargement" (29 April 2004) news.amnesty http://news.amnesty.org (accessed 1 April 2007).

106 See Act concerning the Conditions of Accession [2003] OJ L236/33 art 24. Restrictions cannot apply to Cyprus and Malta due to their small size and relative economic strength. The old 15 Member States must not, however, implement measures that are more restrictive than those that applied as at 16 April 2003 (the date of the Accession Treaty): See European Commission "The Transitional Arrangements for the Free Movement of Workers from the New Member States following Enlargement of the European Union on 1 May 2004". For the two new Member States, see Protocol concerning the Conditions and Arrangements for Admission of the Republic of Bulgaria and Romania to the European Union [2005] OJ L157/29 art 20. 
This is commonly known as the "2+3+2-year arrangement", because it requires Member States to declare in May 2006, May 2009 and again in May 2011 whether they will maintain restrictions on access to the national labour market. ${ }^{107}$ Once access to the labour market is secured, then no discrimination between workers from old and new Member States is permitted and EC law on remuneration, tax and social security matters applies.

In February 2006, the European Commission reported that although there had been a rise in migration from the new Member States to the old ones in the two years since accession, it was relatively low (thus dispelling fears that "floods" of eastern Europeans would seek to take advantage of free access to western Europe). Citizens from the new Member States comprised less than one per cent of the working age population in the old Member States, with the exception of Austria $(1.4 \%)$ and Ireland (3.8\%). ${ }^{108}$ By contrast, migration from non-EU countries was much higher. ${ }^{109}$ Given that Sweden and the UK did not experience higher rates of immigration despite having relaxed labour access, the report concluded that there was no evidence to support a direct link between increased migration from the new Member States with a free labour market, and maintaining restrictions may only delay market adjustments and encourage undeclared work. ${ }^{110}$ Thus, "[d]espite fears expressed on the occasion of the successive enlargements free movement of workers has not led to disruption of national labour markets."111 Analysts had in fact predicted this prior to enlargement. Imposing limits, however, helped to "answer domestic political concerns in the context of slowing economies, high unemployment, and anti-immigration sentiment."112

Despite this evidence, on 1 May 2006, three Member States (Austria, Germany and Italy) declared that they would maintain existing employment restrictions; five (Belgium, Denmark, France, Luxembourg and the Netherlands) determined to gradually lift restrictions over the next three years; four Member States (Finland, Greece, Portugal and Spain) decided to remove any

107 Germany and Austria may restrict access to an even greater degree, since they are most likely to be affected by enlargement. A similar format is included in the Accession Treaty of Bulgaria and Romania.

108 European Commission "Communication from the Commission to the Council, the European Parliament, the European Economic and Social Committee and the Committee of the Regions: Report on the Functioning of the Transitional Arrangements set out in the 2003 Accession Treaty (Period 1 May 2004-30 April 2006)" $\operatorname{COM}(2006) 48$ final (8 February 2006), noting in particular reasons why the Irish figure may appear higher (see para 16); see also summary by EurActiv "Free Movement of Labour in the EU-25" (30 May 2006) www.euractiv.com (accessed 1 April 2007). Ireland had no restrictions on its labour market, so is perhaps indicative of the levels of migration which may take place once all barriers on migrant workers are removed.

109 EC "Functioning of Transitional Arrangements", above n 108, para 18.

110 Ibid, paras 19-20.

111 Ibid, para 36.

112 Joanne van Selm and Eleni Tsolakis "EU Enlargement and the Limits of Freedom" (Migration Policy Institute, Washington, 2004). 
existing restrictions; and three (Ireland, Sweden, United Kingdom ${ }^{113}$ ) left their labour markets open. Fears of unemployment were cited as the main reasons for maintaining limitations. ${ }^{114}$ While it is intended that all restrictions will be lifted by May 2009, States may maintain them if they can demonstrate that without them there will be considerable threats or disturbances to the domestic labour market. By 30 April 2011, all restrictions will cease. ${ }^{115}$

Even though the UK did not limit access to the labour market, it restricted access to benefits and housing assistance to those seeking work by tightening the "habitual residence" test, ${ }^{116}$ and requiring job-seekers to register for employment, establishing the "Worker Registration Scheme". 117 For asylum seekers in the UK at the date of accession, the effect was dramatic. ${ }^{118}$ On 5 and 6 April 2004, less than one month before accession, the UK government sent letters to the 1131 asylum seekers in the UK who were to become EU nationals ${ }^{119}$ on 1 May 2004, informing them that they would no longer be entitled to National Asylum Support Service (NASS) support from that date. NASS support is provided to destitute asylum seekers while their claims are being processed, and to unsuccessful claimants pending removal. It comprises accommodation support, subsistence support (equivalent to around $70 \%$ of income support levels) or both. ${ }^{120}$ "EU" asylum seekers were told that they would instead have the option of: (a) registering under the Worker Registration scheme and working (although they were prohibited from registering until 4 May 2004); (b) becoming selfsufficient; or (c) returning to their country of origin. While those who found work would be eligible for income-related benefits and homelessness assistance, the unemployed would not have a right to means-tested benefits or homelessness assistance.

113 The UK never imposed restrictions per se, although does have a workers' registration scheme.

114 For criticisms of this position, see EurActiv, above n 108.

115 van Selm and Tsolakis, above n 112.

116 See Social Security (Habitual Residence) Amendment Regulations 2004.

117 See Accession (Immigration and Worker Registration) Regulations 2004 (with respect to workers from Poland, Lithuania, Estonia, Latvia, Slovenia, Slovakia, Hungry and the Czech Republic); Accession (Immigration and Worker Registration) Regulations 2006 (with respect to workers from the two newest EU Member States as at 1 January 2007, Bulgaria and Romania).

118 See details of entitlements in Refugee Council "Update on Asylum Seekers and the New EU Accession Countries" (Refugee Council Briefing, June 2004); Asylum Support Crisis Response Website www.asylumsupport.org.uk (accessed 1 March 2007).

119 UK legislation refers to "EEA nationals", which is wider than simply nationals of the 27 Member States, including persons from Iceland, Liechtenstein, Norway and Switzerland: see for example Immigration (European Economic Area) Regulations 2006 s 2.

120 Home Office "National Asylum Support Service (NASS): Frequently Asked Questions" (March 2006) www.ind.homeoffice.gov.uk (accessed 1 March 2007). 
Given the outcry over this sudden and draconian move, the government was forced to change its policy on 29 April 2004, ordering that no evictions would take place until each case had been individually reviewed. A test case heard by Justice Collins in the High Court on 4 May 2004 prevented NASS support from being withdrawn at the date of accession, and gave leave for judicial review. ${ }^{121}$ On 7 May 2004, the Home Office agreed to a period of grace for asylum seekers to find work. Provisional figures suggested that as of 14 May 2004, 571 of the 1131 cases remained in NASS accommodation, and 108 continued to receive cash only support. ${ }^{122}$

Following the Court of Appeal's decision of 21 May 2004 in Limbuela, ${ }^{123}$ upheld by the House of Lords on 3 November 2005, ${ }^{124}$ applicants must now have access to NASS if withholding it would constitute inhuman or degrading treatment, in breach of article 3 of the European Convention on Human Rights (ECHR). ${ }^{125}$ Treatment is inhuman or degrading "if, to a seriously detrimental extent, it denies the most basic needs of any human being."126 Although there is no general public duty to house the homeless or provide for the destitute, a duty will be engaged if an asylum seeker "with no means and no alternative sources of support, unable to support himself, is, by the deliberate action of the state, denied shelter, food or the most basic necessities of life."127 It is impossible to list exhaustively when such treatment may occur, but factors which must be taken into account in that assessment include "age, gender, mental and physical health and condition, any facilities or sources of support available to the applicant, the weather and time of year and the period for which they applicant has already suffered or is likely to continue to suffer privation."128 It is necessary to ask "whether the treatment to which the asylum-seeker is being subjected by the entire package of restrictions and deprivations that surround him is so severe that it can properly be described as

$121 R$ (on the Application of $H$ and D) $v$ Secretary of State for the Home Department (CO/2106/04 and CO/2096/04). See discussion in IAP News No 42 (June 2004) http://www.asylumpolicy.info/iapjune.doc (accessed 30 May 2007).

122 House of Commons Hansard Written Answers for 24 May 2004 (pt 32) col 1397W (Mr Browne). For the media controversy over this issue, see for example Dominic Casciani "Roma Families 'Caught in Asylum Trap"" (4 May 2004) BBC News London http://news.bbc.co.uk (accessed 15 April 2007); "EU Asylum Seekers Lose Benefits" (30 April 2004) BBC News London http://news.bbc.co.uk (accessed 15 April 2007).

123 Secretary of State for the Home Department v Limbuela [2004] EWCA Civ 540 (CA).

$124 R$ v Secretary of State for the Home Department, ex p Adam [2005] UKHL 66.

125 Nationality, Immigration and Asylum Act 2002 c 41, Sch 3 paras 3, 5. For the government's policy directions, see Home Office "EU Accession Nationals on NASS Support: Guidance to NASS Caseworkers on Interview/Assessment Process and Follow-Up Action" (version dated 24 June 2004) www.workingintheuk.gov.uk (accessed 15 April 2007).

126 Adam, above n 124, para 7 Lord Bingham.

127 Ibid, para 7 Lord Bingham.

128 Ibid, para 8 Lord Bingham. See further Pretty $v$ United Kingdom (2002) 35 EHRR 1 para 52 for the types of treatment which fall within the scope of article 3 of the ECHR. 
inhuman or degrading treatment". ${ }^{129}$ In this case, the threshold was met by asylum seekers forced to sleep outdoors due to a denial of State support and the right to work. Factors that contributed to this finding were "the physical discomfort of sleeping rough, with a gradual but inexorable deterioration in their cleanliness, their appearance and their health", "the prospect of that state of affairs continuing indefinitely", their "[g]rowing despair and a loss of self-respect", and the fact that they had "no money of their own, no ability to seek state support and [were] barred from providing for themselves by their own labour". ${ }^{130}$

According to Home Office policy, in most cases an EU national would be able to find employment, "and thus the withdrawal of their asylum support will not result in a breach of Article 3."131 Cases where article 3 might be engaged if support were not provided would be where an individual could not be reasonably expected to find employment, and had no other means of support or shelter available. Suggested indicators in this context include where the individual is physically or mentally disabled, pregnant, ill, illiterate or speaks little or no English. ${ }^{132}$

Asylum applications lodged by EU citizens post-accession (and any claims outstanding at that time) are processed as follows. First, there is a rebuttable presumption that claims by EU nationals are "clearly unfounded". 133 This, coupled with a target of 15 days for the processing of such claims, ${ }^{134}$ may lead to insufficient scrutiny of evidence. Secondly, whereas third country nationals found not to be Convention refugees are automatically considered for human rights-based protection, this does not apply to certain categories of EU nationals. ${ }^{135}$ Thirdly, EU nationals do not have an automatic right to appeal. ${ }^{136}$ As a result, any appeals that are lodged do not have suspensive effect (meaning that individuals can be removed prior to the appeal being heard).

129 Adam, ibid, para 58 Lord Hope (emphasis added).

130 Ibid, para 71 Lord Scott.

131 Home Office "EU Accession Nationals on NASS Support", above n 125.

132 Ibid. Note also discussion of article 8 ECHR claims: 24-27.

133 Nationality, Immigration and Asylum Act 2002, s 94(4); Immigration and Nationality Directorate "Applications from Nationals of the EEA and EU Accession Countries" (2 edn, January 2005) para 6.6. See also the EU requirements imposed under the Procedures Directive, especially arts 23, 29, 30, 36 on "safe third country" provisions and accelerated procedures. These must be read in conjunction with the Qualification Directive. Under art 36 of the Procedures Directive, asylum seekers are not given an opportunity to rebut the presumption of safety of a "European safe third country".

134 Immigration and Nationality Directorate, above n 133, para 6.5.

135 Self-employed persons; providers of services; recipients of services; self-sufficient persons; retired persons; students; or self-employed persons who have ceased activity: EEA Regulations 2000 "qualified persons".

136 See Immigration (European Economic Area) Regulations 2000, as amended by Immigration (European Economic Area) (Amendment No 2) Regulations 2003, regs 33(1C) and (1D). This is the same test as applies under the Nationality, Immigration and Asylum Act 2002 s 94. 
Clearly, this may lead to a breach of the very rights on which the asylum claim is based. Finally, EU nationals are only entitled to NASS support where it is necessary to avoid a breach of the ECHR.

This approach suggests a strong mutual trust in Member States' legal frameworks, but also a reluctance to confront the fact that membership of the EU does not alone remove the possibility for persecution or other forms of serious harm to occur. It assumes that EU citizenship accords equal rights and entitlements to all Member State nationals, when this is plainly not the case. The "seal" of citizenship can obscure inequality.

\section{CONCLUSION}

Considering the framework of migration control within and between the EU Member States, especially in light of EU approaches to external influxes, "free movement" still has boundaries. When the interaction between harmonised asylum laws and enlargement policies is scrutinised, certain EU citizens may curiously end up in a less favourable position than certain third country nationals. The idea that regional laws may be more "democratic" because they are better able to take account of their historical, political, social and cultural context is a double-edged sword. However, criticisms of the manner in which harmonisation has occurred should not be interpreted as an attack on the concept, nor on the EU's potential as a regional law-making body. Regional harmonisation of refugee law is an important step towards consistency, predictability and just outcomes for refugees. However, it must take place within the framework of international norms, and ought to aim for best practice rather than "equalizing down". ${ }^{137}$ Member States should not be able to retreat behind a corporate veil to pursue policies which are at odds with international refugee law, especially when such policies are proclaimed as being consistent with it.

137 This phrase is used in Gilbert, above n 27, 969. 